\title{
MAHKEMELERIMIZDE YEMIN
}

Yazan : Prof. Sabri Şakir ANSAY

Son günlerde Adalet Bakanlığının Ceza Muhakemeleri Usulü Kanununda bazı değişiklikleri ihtiva eden bir tâdil tasansı hazırlayarak Büyük Millet Meclisine sunduğu gazetelerde yayınland. Sanıyorum ki Muhterem Bakanın bir radyo konuşmasinda da bu tadilden bahsedildi. Kanun yapma ve değiştirme hususunda gösterilen isticallerden ötedenberi konferans, makale ve kitaplarda pek de haksız olmayarak şikâyetler olduğu, işitildiiğ malûmdur. Filhakika bazı kanunlanmız ve kanun maddelerimiz aynı mesele hakkındaki hal suretlerinin tekran veya onlarla, umumî esaslanmız, prensiplerimizle, hakikî ihtiyaç ve hayatımızla tezat halinde kalmaktadır. Bir kaç yıl evvel vefat eden büyük Alman hukukçusu ve Hukuk Felsefecisi Radbruch der ki ; hukuk soyal hayatın şekilleri ve usul hukuku bunlann tahkik ve icrasma müteallik usul ve âyinin yâni şeklin şekli olan hukuktur. Bir gemi sereninin tepesi nasıl teknenin en ufak hareketine kuvvetle cevap veriyorsa usul hukukunun inkişafinda sosyal hayatın tedricî tahavvülleri sert bir mukabele halinde akisler gösterir. Ve bunlann tevalisi Hegel'in üçlü tekâmül silsilesini hatırlatır.

Biz burada tâdili teklif edilen yemin formülünden bahsedeceğiz. Bu yemin, bilindiği üzere Ceza Usulü Kanununda şahadet beyyinesi için bir takviye vasitasıdrr; hukuk dâvalanna mahsus Usul Kanununda ise şehadet için böyle bir teyid tedbiri olduğu gibi dâvanın ispatı için de müracaat edilecek müstakil bir beyyinedir. Yâni cezả muhakemelerindeki yeminde böyle bir müstakil beyyine rolü ve kuvveti yoktur. Hattâ şahsî dâvalarda suçluya veya savcıya bir taraf yemini teklif edilemez.

Bilindiği üzere eski hukukumuza göre dâvalarda gerek şahide ve gerek tarafa verilen yemin, Allah adına olurdu. Yemin edecek kimse dinî, vicdanî inancını ileri sürerek yemin formülünde bir değiştirme yapamazd. Kanunen (şer'an) muayyen formülü tekrara ve bu dinî formül üzerine yemin etmeğe mecbur tutulur, yemin mutlak surette, herkes için böyle cereyan ederdi. 
Fakat inkâr olunamaz ki yalan şahadetten ve yalan yeminden daima şikâyetler tekerrür etmiştir. Bizim gençliğimizde İstanbul'un Süleymaniye gibi mahkemeler yakınındaki yerlerde açıktan açığa yalancı şahitlerin toplandığ kahveler bile vard.

Hukuk dâvalarnnda yürüyen eski bir kaideye göre beyyine, yani ispat müddeiye, yemin de dâvayı inkâr edene aittir. Kimin müddei ve kimin münkir olduğu eski hukukumuza göre aynca bir ilim teşkil edecek derecede karışı, güç, tamamiyle kazüist bir bahis idi. Bugün beyyine külfeti denen bu mesele o hukukta da dâvanın bel kemiği sayllacak ehemmiyeti haizdir : İspatı getiren, dâvayı kazanacak, getiremiyen kaybedecektir. İspat getirmek, adı üstünde bir külfet, bir zahmet, getirememek bir tehlikedir. İslâmın en saf devrinde bu kaide normâl rolünü ifa etmiş olsa da sonralan ispat mükellefiyeti dâvacılann bilhassa üzerlerine almavı arzu ettikleri bir nimet oldu. Bir çok kimseler bu külfeti kendilerine düşürmek yollann ararlardı. Çünkü hasmın kolayca yemin edeceğinden korkarlard.

Şahadette gerçi tezkiye usulü var idi ise de, bunda en şüpheli bir kimse dahi, şahadeti makbul ve âdil olarak gösterilebilir, tanınabilirdi. Böylece bu delile bir objektivite temin edilemiyordu. Hele tevatür beyyinesinde şahadet sözü de aranmadığından yalan şahadet iyice kolaylaşyorodu.

Tanzimattan sonraki hukuk dâvalannı yargılamaya ait kanunlarda muayyen mikı̀ardaki dâvalar için Fransa'da olduğu gibi şahadet beyyinesi yerine senetle ispat mecburiyetinin kabulü bu endişe ve tehlikeden doğmuştu. Fakat taraf yemini mecelleye bırakılmıs ve statik, kontrolsuz bir byyine olmakta devam etmişti.

1927 de İsviçre'nin Neuchâtel Kantonu Hukuk Usulü Kanunundan alınan Yargilama Usulü Kanunumuzda Lâtin sisteminde görülen senetle ispat mecburiyeti alıkonuldu. Gerek şahit ve gerek taraf yemini Allah sözü yanına namus sözü ilâve edilerek formüllendi ve Alman Ceza Muhakeme usulünden alınan, Ceza Yarglama Usulü Kanununda ise şahit yemininin vicdan ve namus üzerine verilmesi kabul edildi (Nitekim noterlere de 4166 numaralı kanun mucibince bu dairede yemin ettirilmektedir). Yâni ceza tahkikatında şahide Büyük Millet Meclisi âzasına verilen yemin gibi lâik bir yemin ettirilirken hukuk dâvalannda şahit ve taraf yemini, dinî ve lâik mahiyette mürekkep bir formül halini ald.

Şimdi Ceza Muhakemeleri Usulü Kanunundaki şahadet yemininin hukuk dâvalannda görülen yemin formülü dairesinde değiştiriłmesi, 
denildiği gibi orada dinî formül kullanılmaksızın yapılan şahadetlerin daha çok yalan olduğunun tesbit edilmiş olması vakıasına mı müstenittir? Hukuk dâvalan ile ceza dâvalannda dinlenen şahitler yalan şa. hadette bulunanlann birincilerde daha az, ikincilerde daha çok olduğu hangi sağlam istatistiklerle anlaşılmıştır ? Hukuk, sosyal hayatın, dünya münasebatının, bir düzeni olduğuna göre bu durumda bugün mevcut kanunu değiştirecek ehemmiyette ne gibi bir değişiklik olmuştur. Doğruluğu bizde ve büyük medenî âlemde uzun tecrübeler ve tetkikler neticesinde kabul edilen prensipten aynlmak, dönmek için bir zaruret var mıdır ? Biz yanıldığımızı zannetmiyerek hukuk yargılama kanununa giren isabetsiz yemin formülünün anayasa dairesinde ve nihayet birtakım kanunlarda olduğu gibi tashih edilmesini ve umumiyetle yemin formülünün, yemin edecek kimsenin inancına bırakılarak Allay veya vicdan (namus üzerine) - ki Neuchâtel kanununda da böyledir - teminat sekilleri arasinda muhayyer burakacak surette tertip edilmesini beklerdik. Bu bir taklit, özenme değil bugünün tabiî ve zarurî bir emri olsa gerektir. Şu da hatıra gelir : Eğer ancak Allah adina verilecek bir doğruluk teminatı ile inanılır kuvvet ve kat'iyette bir kanaat elde edilecekse bunu neden yalnız mahkemelerde mecburî kılarak mahkeme dışında — hükûmet yemini denilen yeminde — böyle bir teminat lüzumsuz sayılmalıdır.

Namus, vicdan, şeref gibi şahsiyete müteallik kıymetler elbette küçümsenecek kıymetler değildir. Bu kıymetleri benimsemiyenin din ile ilgisine, dine hürmet ve saygı göstereceğine pek inanılamaz. Biz medenî bir cemiyet olduğumuzu iddia ve bütün müesselerimizi de bu yolda ihya ederek ilerleme azim ve savaşında iken buna yakışır surette şahidin, veya tarafın " doğru söyliyeceğim veya söylediğim, söyliyeceğim sözlerin doğruluğuna söz veriyorum " demesi yalan şahadet ve yalan yeminin hukukî ve cezaî neticelerini vermeğe yeter görülmek icabec̉erken kanunlarımızın manevî, terbiyevî nüfuzlarını sakat istikamełlere tevcih etmemiz yanlıs olsa gerektir.

Yeminli olsun olmasın şahadetin ve taraf yemininin sübjektif birer beyyine olmasına ve bu mahiyeti ile çürüklüğüne binaen psikologlar, usulcüler bunlara karşı daima ihtiyat tavsiye etmektedirler ve haklıdırlar. Çünkü yalnız bilerek yalancılık edilmez, iyi niyetle doğru sanarak hafızanın zaafı, unutkanlı, telkin gibi bir takım nefsì, haricî tesirler altında yalancilıklar mümkündür.

Bir takım memleketler yemini, kanunlarmdan bütün bütün çlkarmışlardır. Onun yerine taraf, taraflan isticvap suretiyle hakikate ulaş- 
mak yolunu tutmuşlardur. Bir hukukçunun dediği gibi iyi, tecrübeli bir Yargıç tarafın veya șahidin ağzından hakikati olgun bir meyva gibi kolaylkkla olmasa bile önüne düşürebilir ; terlemesine lüzum olmaksızın ağacı biraz sallaması kâfi gelebilir. Hele bizim Hukuk Usulü Kanunumuzda olduğu gibi hâkimi sımsıkı bağlayan taraf yemini oldukça tehlikelidir. SSahadetin olduğu gibi hukuk dâvalannda taraf yemininin de yargıcın takdirine bırakılması pekâlâ düşünülebilir.

Avrupa ve Amerika'da yaşayan, Allahı tanıan, dindar bir hiristiyan tarikatı mensuplan Allah namına yemini aslâ kabul etmezler bilhassa Mennunit'ler gibi. Bunlar yeminin ve hattâ dâvalann aleyhindedirler. $\mathrm{Bu}$ gibilerden yemin yerine sadece doğru söyliyeceklerine söz teminatı alınır. Medenî Kanunumuzun 150 nci maddesinde " yemin yerine başka teminat alınacağı " na dair olan ifade buna işarettir. Dini bütün bir müslümanın âdî bir para dâvasına Allahı kanştırmamak istemesi de mümkündür. Bu adamı ille Allah adına yemin edeceksin diye zorlamak doğru mudur?

Prof. S. S. ANSAY 